\title{
Peptidases and growth of Lactococcus lactis in milk
}

\author{
I Mierau ${ }^{1}$, ERS Kunji 2, G Venema ${ }^{1 \star}$, B Poolman ${ }^{2}$, J Kok ${ }^{1}$ \\ ${ }^{1}$ Department of Genetics; 2 Department of Microbiology, \\ Groningen Biomolecular Sciences and Biotechnology Institute, \\ University of Groningen, Kerklaan 30, 9751 NN Haren, the Netherlands
}

\begin{abstract}
Summary - To gain a detailed understanding of the function of peptidases of Lactococcus lactis in growth in milk a set of 16 mutants was constructed lacking one or combinations of the following peptidases: PepO, PepN, PepC, PepT, PepXP. Growth experiments in milk showed that most of the mutants have a decreased growth rate, the general trend being that the more peptidases are inactivated the slower the mutant grows. A mutant lacking all five peptidases grows more than 10 times slower than the wild type. The activities of the cell envelope-associated proteinase (PrtP), of the oligopeptide transport system (Opp) and of peptidases still present in a mutant, were not influenced by its lack of certain peptidases or its decreased growth rate. Therefore the slow growth phenotype was directly caused by the absence of the peptidases and the consequent decreased capacity to release amino acids needed for growth. Furthermore, peptide catabolism was investigated in vivo using a chemically defined medium and a variety of peptides. The study presented shows for the first time that in milk at least PepO, PepN, PepC and PepT are directly involved in the release of amino acids needed for growth.
\end{abstract}

\section{Lactococcus lactis / peptidase / mutant / growth / transport}

Résumé - Rôle des peptidases dans la croissance de Lactococcus lactis sur lait. Afin de mieux comprendre le rôle des peptidases de L lactis au cours de la croissance sur lait, 16 mutants chez lesquels il manque une ou plusieurs des peptidases suivantes : PepO, PepN, PepC, PepT, PepXP ont été construits. Des expériences de croissance sur lait ont montré que la plupart de ces mutants ont une croissance ralentie et ce d'autant plus que le nombre de peptidases mutées est élevé. Un mutant qui a perdu les cinq activités peptidasiques pousse dix fois moins vite que la souche sauvage. Les activités de la protéase associée aux enveloppes, du système de transport des oligopeptides et des peptidases encore présentes chez un mutant ne sont pas affectées par la perte de certaines peptidases ou par la diminution du taux de croissance. La croissance plus lente des mutants est donc directement causée par l'absence des peptidases et la capacité plus faible des souches à libérer les acides aminés nécessaires à la croissance. D'autre part, le catabolisme des peptides a été étudié in vivo dans un milieu de croissance chimiquement défini et pour un certain nombre de peptides. Le travail présenté montre pour la première fois que dans le lait au moins $P e p O, P e p N, P e p C$ et PepT sont directement impliquées dans la libération des acides aminés nécessaires à la croissance.

Lactococcus lactis / peptidase / mutant / croissance / transport

\footnotetext{
* Correspondence and reprints
} 


\section{GROWTH OF LACTOCOCCUS LACTIS IN MILK}

Over the last 10 years, we have witnessed a gradual unfolding of our understanding at the molecular level of how the multiple amino acid auxotroph Lactococcus lactis grows to high cell densities in milk. Initial observations showed that a strain devoid of its extracellular proteolytic capacity can only reach a final cell density of $1 / 4$ to $1 / 10$ of that of a wild type strain. This indicated that $L$ lactis at a cell density of about $10^{8}$ cells $/ \mathrm{ml}$ has exhausted the low molecular mass nitrogen sources in milk and depends completely on the degradation of casein (Law and Kolstad, 1983; for a recent, excellent study see Juillard et al, 1995b).

The first milestone in our understanding arose from biochemical, immunological and genetic analyses of the cell envelope-associated proteinase (PrtP), which initiates the breakdown of casein. In contradiction to earlier speculations only one type of enzyme is present in a given strain. Different strains can have proteinases which degrade casein with different specificities (Kok and de Vos, 1994). A recent reinvestigation of the breakdown products of $\beta$-casein by a PI-type proteinase showed that more than 100 sometimes overlapping peptides with 4 to 30 amino acid residues are formed (Juillard et al, 1995a).

For a long time it was believed that the peptides released from casein by PrtP were further degraded extracellularly and mainly transported by a di-tripeptide transport system (DtpT) (for reviews see Laan et al, 1989; Smid et al, 1991). Now we know that the essential component for the incorporation of casein-derived peptides is the oligopeptide transport system (Opp) and that this system can translocate peptides consisting of up to at least eight amino acid residues. Mutations in opp lead to a severely decreased capacity of $L$ lactis to grow in milk, whereas mutations in dtpT have no effect. Moreover, no further evidence was found for extracellular peptide hydrolysis by enzymes other than PrtP (Tynkkynen et al, 1993; Kunji et al, 1995). Thus, a simple two- step process provides the cell with casein-derived peptides: PrtP degrades casein into a variety of oligopeptides which are then incorporated by the Opp system. Apart from being simple, this system is also very effective since loss by diffusion of small peptides and amino acids as products of extracellular peptide degradation is circumvented.

The last critical step in the cascade of casein-breakdown is the intracellular hydrolysis of peptides to the amino acids needed for growth. In contrast to the wealth of knowledge accumulated about PrtP and Opp only little is known about the biological function of the peptidases of $L$ lactis. In this paper an overview is given on the role of peptidases in peptide degradation and, consequently, for growth in milk.

\section{THE PEPTIDASES OF L LACTIS}

Table I gives an inventory of peptidases purified from $L$ lactis. From many of these enzymes the genes have been cloned and their nucleotide sequence has been determined (most of the data are reviewed by: Kok and de Vos, 1994; PepF: Monnet et al, 1994; PepV: Vongerichten et al, 1994; PepP: Mars and Monnet, 1995; PepA: I'Anson et al, 1995; PepF': Monnet, personal communication; PepO' and PepV: Mierau, unpublished results).

The peptidases can be divided in two groups: i) endopeptidases; and ii) aminopeptidases. No carboxypeptidases have been identified so far. The aminopeptidases can be further subdivided according to their substrate specificities. Group (a) has a broad substrate range and can hydrolyse a wide variety of peptides whereas group (b) peptidases serve specialized functions and 
Table I. Peptidases in $L$ lactis.

Peptidases de L lactis.

Peptidase

Molecular mass

( $k D a)$

(i) Endopeptidases

PepF

PepF'

PepO

PepO'

(ii) Aminopeptidases

(a) Broad specificity

PepN

PepC

PepT

PepV

(b) Special tasks

PepA

$\mathrm{PCP}$

PepXP

PepP

PIP

PRD

98

98

70

70

$\begin{array}{ll}95 & A-B-C-D \ldots \\ 50 & A-B-C-D \ldots \\ 46 & A-B-C \\ 49 & A-B\end{array}$

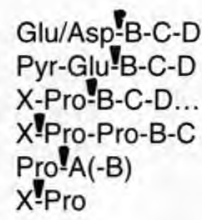

Met-enkephalin

? (Met-enkephalin)

$\begin{array}{ll}43 & \text { Glu/Asp-B-C-D } \\ 26 & \text { Pyr-Glu-B-C-D } \\ 90 & \text { X-Pro-B-C-D... } \\ 45 & \text { X-Pro-Pro-B-C } \\ 50 & \text { Pro-A(-B) } \\ 43 & \text { X-Pro }\end{array}$

$n t-\operatorname{Seq}$

Mutant
Yes

No

Yes

No

$\begin{array}{ll}\text { Yes } & \text { Yes } \\ \text { Yes } & \text { No } \\ \text { Yes } & \text { Yes } \\ \text { Part } & \text { No }\end{array}$

Yes

Yes

$\begin{array}{ll}\text { Yes } & \text { Yes } \\ \text { Yes } & \text { No }\end{array}$

$\begin{array}{ll}\text { Yes } & \text { Yes } \\ \text { Yes } & \text { No }\end{array}$

$\begin{array}{ll}\text { Yes } & \text { Yes } \\ \text { Yes } & \text { No } \\ \text { Yes } & \text { Yes } \\ \text { No } & \text { No } \\ \text { No } & \text { No } \\ \text { No } & \text { No }\end{array}$

hydrolyse peptide bonds involving proline, glutamic acid, pyroglutamic acid and aspartic acid. This classification is based on in vitro analyses of purified enzymes and does not permit to draw conclusions on the function of the peptidases in vivo. To allow an assessment of the biological role of the peptidases, mutants of $p e p F$, pepO, pepN, pep $T$, $p e p A$, and pepXP have been constructed in several laboratories and analysed for their capacity to grow in milk (Mayo et al, 1993; Mierau et al, 1993; Monnet et al, 1994; de Vos and Siezen, 1994; Mierau et al, 1994; I'Anson et al, 1995). None of these mutants differed significantly from the wild type in growth rate and acid production. Therefore, either other peptidases with overlapping specificities can take over the function of a missing peptidase, as has been observed in E coli (Miller and Schwartz,
1978) and S typhimurium (Miller and Mackinnon, 1974), or the enzymes in question are not involved in the degradation of casein-derived peptides.

\section{MULTIPLE PEPTIDASE MUTANTS AND THEIR GROWTH IN MILK}

Because of the possible overlapping specificities of the peptidases present in L lactis, only the construction of multiple mutants allowed a detailed analysis of the role of the various enzymes in the casein degradation route. A targeted deletion method, recently developed in our laboratory (Leenhouts and Venema, 1993), was used to construct a set of 16 mutants lacking up to all five of the following peptidases: PepO, PepN, PepC, PepT and PepXP (table II) (Mierau, 
manuscript in preparation). All mutants were grown in milk and the growth rate and acid production was determined. With respect to growth rate, the mutants can roughly be divided into six groups (table III).

Whereas inactivation of PrtP or Opp leads to a severe growth defect in milk, peptidase mutations mainly influence the growth rate of the strain. In general, the more peptidases are lacking the slower the mutant grows. In addition, we observed that the mutants (XN)-, (XTN)-, and (XTON)- had a longer lag phase than the other strains. Interestingly, some peptidase mutations have a more pronounced effect than others. For instance, the absence of PepN caused a significant decrease of the growth rate (this observation differs from an earlier investigation, de Vos and Siezen, 1994); all other single mutations left the strains unaffected. Furthermore, the combination of the pep $N$ mutation with other peptidase mutations caused a severe reduction in growth rates (see $\left.(\mathrm{ON})^{-},(\mathrm{CN})^{-},(\mathrm{XTON})^{-}\right)$, while additional inactivation of pepXP has no effect (see table III, eg $\left.(X T)^{-},(X O)^{-},(X N)^{-}\right)^{-}$.

\section{WHY DO PEPTIDASE MUTANTS GROW SLOWER IN MILK?}

Thus far, nothing is known about links in the regulation of the different components of the proteolytic system. If these exist, the slower growth rates of the peptidase mutants in milk could have a variety of reasons. The lack of (a) peptidase(s) could influence the expression or activity of PrtP or Opp or other peptidases in the cell and, in this way, cause the observed lower growth rates. Therefore, we have measured the activity of PrtP and Opp in the wild type strain and in selected mutants. In none of the mutants investigated did we observe an effect on the activity of PrtP or Opp relative to the wild type. We have also monitored the presence of PepN, PepC, PepT, PepV and PepXP and did not find major differences between mutants and the wild type strain. From these results we can conclude that the lower growth rates in milk are the direct result of the loss of the peptidases and the concomitant decreased capacity to degrade casein-derived peptides into the

Table II. Peptidase negative mutants of $L$ lactis MG 1363.

Mutants peptidase- de L lactis MG 1363.

\begin{tabular}{|c|c|c|c|c|}
\hline $\begin{array}{l}\text { Single } \\
\text { mutants }\end{array}$ & $\begin{array}{l}\text { Double } \\
\text { mutants }\end{array}$ & $\begin{array}{l}\text { Triple } \\
\text { mutants }\end{array}$ & $\begin{array}{l}\text { Four-fold } \\
\text { mutants }\end{array}$ & $\begin{array}{l}\text { Five-fold } \\
\text { mutants }\end{array}$ \\
\hline $\begin{array}{l}\text { рерXP } \\
\text { pepN } \\
\text { pepC } \\
\text { pepT } \\
\text { pepO } \\
\Delta о р p-p e p O\end{array}$ & $\begin{array}{l}\text { рерХРрерТ } \\
\text { рерNрерP } \\
\text { рерNрерC } \\
\text { рерXРpеpO } \\
\text { рерОрерN }\end{array}$ & $\begin{array}{l}\text { рерХРрерТрерО } \\
\text { рерХРрерТрерN }\end{array}$ & $\begin{array}{l}\text { рерХРрерТрерОрерС } \\
\text { рерХРрерТрерОрерN } \\
\text { рерХРрерТрерNрерС }\end{array}$ & рерХРрерТрерОрерСрерN \\
\hline
\end{tabular}

All mutants are available also with the lactose-proteinase plasmid pLP712 (Gasson, 1983).

Tous les mutants sont également disponibles avec le plasmide lactose-protéinase pLP712 (Gasson, 1983) 
Table III. Growth rates of peptidase mutants in milk.

Taux de croissance des mutants peptidase- dans le lait.

\begin{tabular}{lll} 
Group & $\begin{array}{l}\text { Approx } \\
\text { growth rate }\end{array}$ & Strains \\
\hline 1 & 0.65 & $\mathrm{WT}, \mathrm{O}^{-*}, \mathrm{C}^{-}, \mathrm{T}^{-}, \mathrm{X}-,(\mathrm{XT})^{-},(\mathrm{XO})^{-}$ \\
2 & 0.52 & $\mathrm{~N}^{-},(\mathrm{XNN})^{-}$ \\
3 & 0.41 & $(\mathrm{XTO})^{-},(\mathrm{XTOC})^{-}$ \\
4 & 0.31 & $(\mathrm{NC})^{-},(\mathrm{ON})^{-},(\mathrm{XTN})^{-},(\mathrm{XTON})^{-}$ \\
5 & 0.14 & $(\mathrm{XTNC})^{-}$ \\
6 & 0.05 & $(\mathrm{XTOCN})^{-}$
\end{tabular}

\footnotetext{
* Absence of a peptidase is indicated with a one letter code derived from the enzyme name. For PepXP, X was used in order to avoid overlap with PepP.

* L'absence d'une peptidase est indiquée par un code d'une lettre issue du nom de l'enzyme. Pour PepXP, X a été utilisé de façon à éviter la confusion avec PepP.
}

amino acids needed for growth. As a slower supply of amino acids leads to slower growth, the growth rate of a certain peptidase mutant in milk is a direct indication of the role of the lacking peptidase(s). With these experiments it was for the first time clearly shown that PepN, PepC, PepT and $\mathrm{PepO}$ are directly involved in the degradation of casein-derived peptides. Contrasting to earlier speculations, which ascribed to PepXP an important role in the hydrolysis of casein-derived peptides, because of their high proline content and the high incidence of the proline residue preceding an essential amino acid (Smid et al, 1991), no clear effect of the absence of PepXP was observed (Mierau, in preparation).

\section{UTILIZATION OF PEPTIDES BY L LACTIS}

Chemically defined medium (CDM) was used to study the individual contribution of peptidases to the degradation of selected peptides. One of the amino acids which can not be synthesized by $L$ lactis and has, therefore, to be obtained from the growth medium is leucine. CDM with a complete amino acid mixture allows growth of the wild type and all of the mutant strains. If leucine is omitted from the medium none of the strains can grow, confirming that this amino acid is essential (table IV). If leucine is added as part of a peptide, only those strains can grow which have the peptidase activity(ies) necessary to release leucine from this peptide. For this investigation the following peptides were used: Leu-Gly, Leu-Gly-Gly, GlyPhe-Leu, Leu-Gly-Pro, Ala-Pro-Leu, Gly-Leu-Gly-Leu, and Leu-enkephalin. As expected, the wild type and all mutants could grow with Leu-Gly as the source for leucine since a dipeptidase is still present in the strains. The growth response of the mutants on the other peptides allowed us to assess, qualitatively, the in vivo role of the various peptidases in the degradation of these 
Table IV. Growth of peptidase mutants on model peptides. Croissance de mutants peptidase- sur des peptides modèles.

\begin{tabular}{|c|c|c|c|c|c|c|c|c|}
\hline Strain & $A A$ & -Leu & $L G$ & LGG & GFL & LGP & $A P L$ & GLGL \\
\hline Wild type & +++ & - & +++ & +++ & +++ & +++ & +++ & +++ \\
\hline $\mathrm{T}^{-}$ & +++ & - & +++ & ++ & +++ & nd & +++ & +++ \\
\hline $\mathrm{N}^{-}$ & +++ & - & +++ & +++ & +++ & nd & +++ & +++ \\
\hline$x^{-}$ & +++ & - & +++ & +++ & +++ & nd & $(+)$ & +++ \\
\hline$(\mathrm{CN})^{-}$ & +++ & - & +++ & +++ & +++ & +++ & +++ & - \\
\hline$(X T)^{-}$ & +++ & - & +++ & ++ & +++ & +++ & $(+)$ & +++ \\
\hline (XTN)- & +++ & - & +++ & - & ++ & +++ & - & - \\
\hline (XTOC)- & +++ & - & +++ & ++ & +++ & +++ & $(+)$ & +++ \\
\hline (XTON)- & +++ & - & +++ & - & ++ & +++ & - & - \\
\hline (XTNC)- & +++ & - & ++ & - & - & - & - & - \\
\hline
\end{tabular}

Minimal medium with amino acids (AA), with AA lacking leucine (-Leu) and with peptides as leucine source ( + , growth; -, no growth, nd, not determined).

Milieu minimum avec acides aminés (AA), avec acides aminés sans leucine (-Leu) et avec peptides comme source de leucine (+, croissance ; -, pas de croissance; nd, non déterminé).

model peptides. Leu-Gly-Gly is mainly broken down by PepT and with a lower efficiency by $\mathrm{PepN}$, because a strain which lacks PepT grows $25-40 \%$ slower than the wild type, whereas a strain lacking PepN was not impaired. Strains lacking PepT and PepN cannot grow with this peptide, indicating that no other peptidase is present which is capable to hydrolyse it (table IV). This is surprising since in vitro studies had shown that PepC is able to degrade LeuGly-Gly (Neviani et al, 1989). The results demonstrate that knowledge obtained from in vitro experiments can not be directly applied to the in vivo situation. The peptide Gly-Phe-Leu is efficiently degraded by both PepT and PepN and less so by PepC, while Leu-Gly-Pro is degraded equally well by PepT, PepN and PepC. This shows that the failure of PepC to break down Leu-Gly-Gly is not due to the low concentration of the enzyme in the cell but due to a low or missing activity towards this substrate. Moreover, the study with these three peptides shows that the same peptide can be broken down by different enzymes, although sometimes with a lower specific activity leading to a decreased growth rate. It also demonstrates an approach to studying enzyme specificity in vivo. The peptide AlaPro-Leu is mainly broken down by PepXP. No other enzyme in the cell can replace this activity. A strain lacking PepXP grows 10 times slower than the wild type. A very low activity towards Ala-Pro-Leu was observed for PepN and PepT. If these two peptidases are inactivated as well, growth decreased to near the detection limit (table IV). The peptide Gly-Leu-Gly-Leu can be degraded either by PepN alone or by a combination of PepC and PepT. PepC can cleave off the first glycine residue but is unable to degrade Leu-Gly-Leu. PepT, which is not able to degrade the tetrapeptide, can further hydrolyse Leu-Gly-Leu. In this experiment the cooperation of peptidases was demonstrated. Lastly, the five-fold mutant (XTOCN)- could still grow on Leuenkephalin, whereas an opp mutant, used to show that no extracellular degradation of the substrate takes place (Tynkkynen et al, 1993), could not (Mierau, in preparation). 
Apparently, still other yet not identified peptidases are present in the mutants which can liberate leucine from this substrate. One option would be an endopeptidase which could cooperate with the dipeptidase present in the cells. Indeed, we have recently identified in MG1363 an endopeptidase with more than $90 \%$ amino acid sequence identity to PepO (Mierau, unpublished results).

The following general conclusions can be drawn from these data: In $L$ lactis peptidases with both overlapping and singular substrate specificities are present, which form a network of peptide degradation routes. In this network one peptide can be broken down by alternative pathways. Different peptides can be broken down by one pathway as well as by independent pathways. The flexibility of this network ensures that every possible peptide can be broken down very effectively. Furthermore, in the presence of a complex mixture of peptides, as, eg, in milk, single and some double mutations have no effect on the growth rate because alternative peptides and degradation routes can be used to liberate essential amino acids. Introduction of more mutations causes a stepwise decrease of the growth rate since optimal breakdown routes become blocked, and other routes which work less efficiently have to be used.

\section{CONCLUSION}

Ten years after the first report on the cloning of a proteinase gene ( $p r t P$ ) of $L$ lactis (Kok et al, 1985) we start do develop a clear picture of the complete course of the degradation of casein into amino acids. The system is amazingly simple and effective: one extracellular proteinase hydrolyses casein into oligopeptides of which those with the proper size are translocated into the cell by one ATP-dependent oligopeptide transport system. Once inside the cell a few peptidases with broad specificities degrade these peptides into amino acids. Some peptides containing special amino acids are degraded by specific peptidases.

Many details of the peptidase system still remain to be worked out. Also, almost nothing is known about the possible (co)regulation of the three components of the proteolytic system, PrtP, Opp and peptidases. Recently, it was suggested that small peptides have an inhibitory effect on the expression of prtP (Marugg et al, 1995). Also the function of the di-tripeptide transport systems (DtpT and DtpP)(Hagting et al, 1994; Foucaud et al, 1995) and that of the different amino acid transport systems during growth in milk remains to be elucidated.

\section{REFERENCES}

de Vos WM, Siezen RJ (1994) Engineering pivotal proteins for lactococcal proteolysis. In: Biochemistry of milk products (Andrews AT, Varley J, eds) Royal Society of Chemistry Cambridge, England, 56-71

Foucaud C, Kunji ERS, Hagting A, Richard J, Konings WN, Desmazeaud M. Poolman B (1995) Specificity of peptide transport systems in Lactococcus lactis: evidence for a third system which transports hydrophobic di- and tripeptides. J Bacteriol 177. $4652-4657$

Gasson MJ (1983) Plasmid complements of Streptococcus lactis NCDO712 and other lactic streptococci after protoplast-induced curing. J Bacteriol 154, 1-9

Hagting A, Kunji ERS, Leenhouts KJ, Poolman B, Konings WN (1994) The di- and tripeptide transport protein of Lactococcus lactis. J Biol Chem 269, 1139111399

I'Anson KJA, Movahedi S, Griffin HG, Gasson MJ, Mulholland $F$ (1995) A non-essantial glutamyl aminopeptidase is required for optimal growth of Lactococcus lactis MG 1363 in milk. Microbiology 141, 2873-2881

Juillard V, Laan $\mathrm{H}$, Kunji ERS, Jeronimus-Stratingh CM, Bruins AP, Konings WN (1995a) The extracellular $\mathrm{PI}$-type proteinase of Lactococcus lactis hydrolyzes $\beta$-casein into more than one hundred different oligopeptides. J Bacterio/ 177, 3472-3478

Juillard V, Le Bars D, Kunji ERS, Konings WN, Gripon JC, Richard J (1995b) Oligopeptides are the main source of nitrogen for Lactococcus lactis during growth in milk. Appl Environ Microbiol 61, 3024-3030

Kok J, van Dijl JM, van der Vossen JMBM, Venema G (1985) Cloning and expression of a Streptococcus cremoris proteinase in Bacillus subtilis and Streptococcus lactis. Appl Environ Microbiol 50, 94-101 
Kok J, de Vos WM (1994) The proteolytic system of lactic acid bacteria. In: Genetics and Biotechnology of Lactic Acid Bacteria (Gasson M, de Vos W, eds) Blackie and Professional, London, UK, 169-210

Kunji ERS, Hagting A, de Vries CJ, Juillard V, Haandrikman AJ, Poolman B, Konings WN (1995) Transport of $\beta$-casein-derived peptides by the oligopeptide transport system is a crucial step in the proteolytic pathway of Lactococcus lactis. J Biol Chem 270, 1569-1574

Laan H, Smid EJ, Tan PST, Konings WN (1989) Enzymes involved in the degradation and utilization of casein in Lactococcus lactis. Neth Milk Dairy J $43,327-345$

Law BA, Kolstad J (1983) Proteolytic systems in lactic acid bacteria. Antonie van Leeuwenhoek 49, 225245

Leenhouts KJ, Venema G (1993) Lactococcal plasmid vectors. In: Plasmids. A practical approach (Hardy $K G$, ed) Oxford University Press, New York, 65-94

Mars I, Monnet V (1995) An aminopeptidase P from Lactococcus lactis with original specificity. Biochim Biophys Acta 1243, 209-215

Marugg JD, Meijer W, van Kranenburg R, Laverman P, Bruinenberg PG, de Vos WM (1995) Medium-dependent regulation of proteinase gene expression in Lactococcus lactis: Control of transcription initiation by specific dipeptides. J Bacteriol 177, 2982-2989

Mayo B, Kok J, Bockelmann W, Haandrikman A, Leenhouts KJ, Venema G (1993) Effect of X-prolyl dipeptidyl aminopeptidase deficiency on Lactococcus lactis. Appl Environ Microbiol 59, 2049-2055

Mierau I, Tan PST, Haandrikman AJ, Kok J, Leenhouts KJ, Konings WN, Venema G (1993) Cloning and sequencing of the gene for a lactococcal endopep- tidase, an enzyme with sequence similarity to mammalian enkephalinase. J Bacteriol 175, 2087-2096

Mierau I, Haandrikman AJ, Velterop O, Tan PST, Leenhouts KL, Konings WN, Venema G, Kok J (1994) Tripeptidase gene ( $\rho e p T$ ) of Lactococcus lactis: Molecular cloning and nucleotide sequencing of pep $T$ and construction of a chromosomal deletion mutant. J Bacteriol 176, 2854-2861

Miller CG, Mackinnon K (1974) Peptidase mutants of Salmonella typhimurium. J Bacteriol 120, 355-363

Miller DG, Schwartz G (1978) Peptidase-deficient mutants of Escherichia coli. J Bacteriol 135, 603611

Monnet V, Nardi M, Chopin A, Chopin MC, Gripon JC (1994) Biological and genetic characterization of PepF, an oligopeptidase from Lactococcus lactis. J Biol Chem 269, 32070-32076

Neviani E, Boquien CY, Monnet V, Phan Thanh L, Gripon JC (1989) Purification and characterization of an aminopeptidase from Lactococcus lactis subsp cremoris AM2. Appl Environ Microbiol 55, 2308-2314

Smid EJ, Poolman B, Konings WN (1991) Casein utilization by lactococci. Appl Environ Microbiol 57 , 244-452

Tynkkynen S, Buist G, Kunji E, Kok J, Poolman B,Venema G, Haandrikman A (1993) Genetic and biochemical characterization of the oligopeptide transport system of Lactococcus lactis. J Bacteriol 175, 7523-7532

Vongerichten KF, Klein JR, Matern H, Plapp R (1994) Cloning and nucleotide sequence analysis of pepV a carnosinase gene from Lactobacillus delbrueckii subsp lactis DSM 7290, and partial characterization of the enzyme. Microbiology 140, 2591-2600 